\title{
TYPES OF FIGURATIVE LANGUAGE FOUND IN BON JOVI SONG LYRICS
}

\author{
Eufronius Sarino Lembu' ${ }^{1}$, Desak Putu Eka Pratiwi ${ }^{2}$, \\ Komang Dian Puspita Candra ${ }^{3}$ \\ English Study Program Faculty of Foreign Languages, Mahasaraswati \\ Denpasar University, Indonesia ${ }^{123}$ \\ efremlembu17@gmail.com, desak.eka.pratiwi@gmail.com, \\ puspita@yahoo.com
}

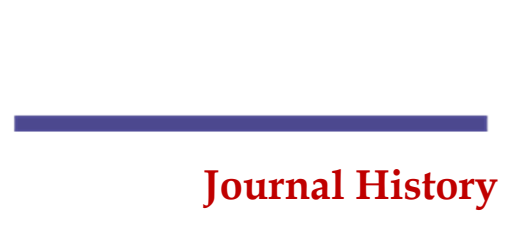

Submitted 27th December 2021 Revised 21 $1^{\text {th }}$ January 2022 Accepted 23rd January 2022 Published 24th January 2022

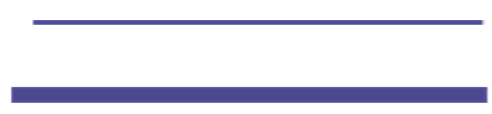

Keywords:

figurative languages, semantics, song lyrics

\begin{abstract}
This study aim to analysis types Figurative language and their meaning found in Bon Jovi song lyrics. In every song we can find many languages that contain figurative language because that's the important element in the song to deliver the meaning to the listener. 'The data source of this study were taken from https://w.azlyrics.com/ which consists of several lyrics that taken by the researcher. The data were collected used the observation method. Whereas the descriptive qualitative method was used to analyse the data in this study. The data were analysed base on theory of figurative language by Knickerbocker and Reninger (1963) and the meaning used the theory by Barthes (1964). The finding of the study analysis 10 types of figurative language base on the song from 2 albums of Bon jovi song lyrics such as 4 types of similes, 1 types of metaphors , 2 types of , 1 type of metonymy, 9 types of hyperboles, 2 types of irony, 1 type of allusion 1 type of paradox with the percentage unfortunately, the writer didn't dead metaphor and Synecdoche in the song lyrics. The types of figurative language contain with the denotative and connotative meaning.
\end{abstract}

\section{INTRODUCTION}


Everyone accepts that language is an all-inclusive, interaction how to communicate sentiments, feelings, signs, and other people in correspondence through language. Here, the scientist will uncover the use of non-literal language in Bon Jovi's melodic poems. In this study the writer will examine the importance of the types of metaphorical language found in melodic poems so that we can imagine the importance of these tones. One of the scientific works that contain metaphorical language is melody. Paying attention to the melody is a very pleasant gesture, but everyone just listens but doesn't understand the non-literal language in the notes. In this research the writer will describe the song rhymes of bon Jovi with the reason that he is one of the extraordinary rock artists who is very famous in the music circle and has many songs until recently they have a new collection even though they are very old but they really exist in the world of music as the melodic musician Bon Jovi points out- really influences the allegorical type of language and has one-sided sentences in examination making it easy for the writer to choose a few sentences of language metaphor to dissect. At some point the language allegory analyzes two things so that you find an interesting explanation in the examination. Allegorical language is either figurative language or hyperbole, a method of saying several different choices of the exact meaning of the word. The author will describe the non-literal language used in the Bon Jovi stanzas and here the essayist completes a study entitled "Non-literal Language Examination in Bon Jovi Melodic Verses.

The connected study was taken from an Article by Yuri and Rosa (2013) named "An Analysis of types of Figurative Language Used in Internet Advertisements ". Their examination expects to decide kinds of hyperbole which broadly utilized by sponsor to advance their items. They found about the similitudes and the differences in the utilization of saying in male and female items. They utilized hypothesis from Perrine (1988: 94) to examine the information. In examining the sorts of interesting expression, they just spotlight on four kinds of saying, including: exemplification, representation, exaggeration, and analogy. They gathered information from promotions distributed on the web. In light of information investigation, it was tracked down that number of information from the men items like 25 representations, 10 illustrations, 8 metaphors, 7 likenesses. In the meantime in female items it was discovered 22 embodiments, 4 representations, 16 metaphors, and 8 likenesses. The distinction between this current investigation and their examination is this current examination were broke down 10 sorts of allegorical language while their examination investigations 4 kinds of the non-literal language. The comparability of this investigation is they center on examination of allegorical language 


\section{METHODS}

The data of this research was taken from the lyrics of Bon Jovi's songs in 2 of his albums such as Crossroad and the album bon jovi 2020. The author chose 11 selected songs from the two albums with the titles: Always, Run away, Bed of Roses, in the arms, Story of love, Bad medicine, Unbroken, I'll be there for you, you give love a bad name, Let it rain, blood in the water. He is one of the legendary singers who still shine in the world of music and his songs have several languages that contain figurative language and his songs are also well known by people in this world. Listen and read carefully the lyrics of the song and repeatedly in order to understand the song, Copy the song lyrics script from https://w.azlyrics.com/ and underline sentences that contain figurative language, Identified and classified the data based on the type of figurative language. Qualitative methods are used to describe the types and meanings of figurative language in Bon Jovi's song lyrics. The second problem is analyzed by using the theory of Barthes to describe the meaning of figurative language found in the lyrics of the song Bon Jovi. In the formal method, the writer presents the data by showing the percentage and tables showing the types of figurative language in the novel. The informal method is used to explain the meaning of the figure of speech contained in the lyrics of the song Bon Jovi.

\section{RESULTS}

\section{RESULTS AND DISCUSSION}

Table 4.1 Figurative Languages Used in Ten Song Lyrics of Bon Jovi

\begin{tabular}{l|lcc}
$\mathbf{N} 0$. & Types of Figurative languages & Occurrence & Percentage \\
\hline $\mathbf{1}$ & Simile & 4 & $19,04 \%$ \\
\hline $\mathbf{2}$ & Metaphors & 1 & $4,76 \%$ \\
\hline $\mathbf{3}$ & Personification & 2 & $9,52 \%$ \\
\hline $\mathbf{4}$ & Metonymy & 1 & $4,76 \%$ \\
\hline $\mathbf{5}$ & Hyperboles & 9 & $42,85 \%$ \\
\hline $\mathbf{6}$ & Irony & 2 & $9,52 \%$ \\
\hline $\mathbf{7}$ & Allusion & 1 & $4,76 \%$ \\
\hline $\mathbf{8}$ & Paradox & $\mathbf{2 1}$ & $4,76 \%$ \\
\hline & TOTAL $(\mathbf{N})$ & & $\mathbf{1 0 0} \%$
\end{tabular}

\section{DISCUSSION}

From the data above, the researcher puts eight types of figurative language and meaning base on theory used by Knickerbocker and Reninger (1963) and the theory of meaning from Barthes (1964). The total calculation of figurative language in each type were 4 types of similes $(19,04 \%), 1$ types of metaphors $(4,76 \%), 2$ types of personifications $(9,52 \%)$, 1 type of metonymy $(4,76 \%), 9$ types of hyperboles $(42,85 \%), 2$ types of 
irony $(9,52 \%), 1$ type of allusion $(4,76 \%) 1$ type of paradox with the percentage $(4,76 \%)$. The writer analyzing the types and the meaning of figurative languages by using the theory of Knickerbocker and Reninger (1963: 367). In explaining the data, only several best representatives of the data for each section were listed in this part. The analysis of data representatives are described as below.

\section{Simile}

\section{Data 1:}

"Your love like Bad medicine" (Bad medicine line/stanza 1/1)

In the sentence above, there are two words that are stated, namely love and bad medicine. Of course the words have nothing to do because love is the feeling of our heart and the drug shows an object. Bad medicine is something that can be considered expired, so the writer concludes that love is fake.

Base on the theory by Barthes (1964), this sentence is kind of connotative meaning which is the author hide the original meaning. In this case the author tells that the love of a girl is only in the mouth and she always betrays love. As the conceptual meaning of the sentence above explain about the love is too much from the man it can be influence the health. As we know the sentence bad medicine is a sentence that really explains that the drug is a bad drug but in the song the author explains that the drug that the author needs is a drug that can cure disease, therefore the author associates the woman he likes with bad medicine

\section{Metaphor}

\section{Data 2:}

"Oh, oh you're a loaded gun" (you give love a bad name stanza/line 8/3)

The statement above can be categorize as metaphor because there is a comparison between word "you" and "loaded gun" and this sentence without using like or as.

The connotative meaning of the sentence above is that the singer stated that the target he was talking about was an experienced person. There, we can see a gun that is filled with bullets. Conceptual meaning of this sentence is about someone that has a gun with lots of bullets

\section{Personification}

\section{Data 3:}

"I heard your suitcase say goodbye" (i'll be there for you line/stanza 2/1) 
The author compares how an object can leave, as in the lyrics the writer describes an event that can be done by humans and non-humans. Suitcases are non-human and leave as human being.

As the theory from Barthes (1964) the sentences categories as connotative meaning. As we know, the placement of the words suitcase and goodbye are indicates that someone sees a suitcase and thinks that it means that he is left alone by his lover and will never come back to him again. Suitcase is a place to store all items used and goodbye is a human activity that leaves someone behind.

\section{Metonymy}

\section{Data 4:}

"When priests and politicians sell the truth and nothing more that day we'll know what all of this was for (let it rain line/stanza 22/4)

The sentence that has underline they are priests and politicians can be categorized as metonymy because this kind of figurative language states something by using other words that have a connection.

According to Barthes (1964) this kind of denotation which the meaning of the words priest refers to someone leads prayers like in church and the politicians refers to a person who is professionally involved in politics, especially as a holder of or a candidate for an elected office. Therefore, the writer uses this metonymy because it is appropriate to describe the situation

\section{Hyperbole}

\section{Data 5:}

"I'd get down my knees for you and make everything alright (in these arms line/stanza 17/3)

The sentence above is a type of hyperbola figure of speech. As we know the times of hyperbola are very exaggerating and always utter phrases that are difficult for common sense to accept. As in the sentence I'd get down my knees, which means not without having to kneel all the time to get someone's love.

Based on the theory of Barthes (1964) the sentence above is a connotative meaning. In this case is overstatement to describe that the author promises his love so great that he has to kneel in front of a woman. And there is sentences make everything alright which means the promise that everything will be fine. The denotation meaning the sentences get down the knee is the easiest way to ask something and to solve the problem. 


\section{Irony}

\section{Data 6:}

"Darling, you give love a bad name" (you give love a bad name line/stanza 3/1)

The song lyric above can be categorized as irony because there is a satire that expresses darling and bad name which is they have been become a boyfriend and girlfriend but in this song, the author will tell his feeling about what just have done by his girlfriend. In the sentence above, the writer satirizes his lover and feels sorry for his lover's actions not saving him and always avoiding.

As the theory stated by Barthes (1964), the song lyric above was kind of Connotative meaning because According to Barthes (1964: 91), connotative is a system consisting of signifying and a process that unites the former with meaning. So indirectly the singer satirized his lover by saying you gave that love a bad name which means he regrets his lover's behaviour. Denotative meaning from the sentence above is he expresses his feeling of disappointment towards his girl who has given false hope. So that he says the name love is bad.

\section{Allusion}

\section{Data 7:}

"I was born to be service Camp Lejeune just felt like home" (blaze of glory line/stanza 3/1)

The song writer wrote this song lyric by using types of allusion because this lyric is a reference for some well-known place or name even person the words "camp Lejeune" is reference for well-known place which United States military training ground.

Base on explanation above, the lyric related to connotative meaning is the communicative value of an expression over it is purely conceptual content. It is something than the dictionary meaning. The word camp Lejeune it has become such a comfortable place for veterans that they say Camp Lejeune feels like home since they gain a lot of experience during military training.

\section{Paradox}

\section{Data 8:}

"Now they come to take me back, I sleep with one eye open" (blood in the water line/stanza 11/2)

The song lyric above categorize as types of paradox this lyric a statement of which surface, on obvious meaning seems to be illogical, even absurd but making good sense upon closer examination. Paradox is 
also known as a statement that contradicts itself. As in the word "sleep" which is underlined in the lyrics of the song, the author says he has slept but there is also the word "one eye open" which shows he has not been said to be sleeping.

In the song lyric above is related to the kind of connotative meaning. Connotative meaning is communicative value of an expression over is purely conceptual content. The singer said he is sleeping when the storm came but with his eyes open for the sake of the safety of his life and his family because if he slept and closed his eyes, danger would come to him. What might the answer imply and why does it matter? How does it fit in with what other researchers have found (other previous researches and theories)? What are the perspectives for future research?

This section allows you to offer your interpretation and explain the meaning of your results. Emphasize any theoretical or practical consequences of the results.

The Discussion section should be a reasoned and justifiable commentary on the importance of your findings. This section states why the problem is important; what larger issues and what propositions are confirmed or disconfirmed by the extrapolation of these findings to such overarching issues.

\section{CONCLUSION}

The first problem is related to the types of figure of speech, found 10 types of figure of speech from ten Bon Jovi songs in 2 albums such as crossroad and album Bon Jovi 2020 using the theory according to Knickerbocker and Reninger. There are only eight out of ten types of figurative language found in this study. The total data in this study were 21 figurative language data. Based on the table, there are 4 types of similes, 1 type of metaphor, 2 types of personification, 1 type of metonymy, 9 types of hyperbole, 2 types of irony, 1 type of figure of speech, 1 type of paradox with a percentage. Based on the results of the study, the dominant types of figurative language used in the lyrics of this Bon Jovi song are similes and hyperboles because in the song, they express something using other words that have a relationship, namely as metaphors and exaggerated and absurd expressions. As we know that in a song there are many discussions about love where Bon Jovi as a singer tells his personal love story through one song and the singer always gives sweet words to get love from someone they love. In this study, the author is more dominant in finding many sentences that are very excessive, such as hyperbole.

\section{REFERENCES}

Abdul Chaer 2004. Sociolinguistic. Jakarta: Rineka Cipta.

Always song lyrics Retrieved March, 10, 2021 
https:/ / www.azlyrics.com/lyrics/bonjovi/always.html

Bad medicine song lyrics. Retrieved March, 10, 2021 https://www.azlyrics.com/lyrics/bonjovi/badmedicine.html

Barfi Alexandria (2018) "An Analysis of Figurative Language in Michael Bubble Song Lyrics. Thesis. Bali. English Study Program College of Foreign Language University Mahasaraswati Denpasar.

Barthes, Roland. 1964. Elements of Semiology. New York: Hill and Wang. Bed of roses song lyrics Retrieved March, 10, 2021

https://www.azlyrics.com/lyrics/bonjovi/bedofroses.html

Bon Jovi. Retrieved March 26, 2021;

From https:/ / en.wikipedia.org/wiki/Jon_Bon_Jovi

I'1l be there for you song lyrics. Retrieved March, 10, 2021

https://www.azlyrics.com/lyrics/bonjovi/illbethereforyou.html

In these arms song lyrics. Retrieved March, 10, 2021

https://www.azlyrics.com/lyrics/bonjovi/inthesearms.html

Knickerbocker and Willard Reninger (1963) theory of figurative language.

New York: Holt, Rinehart and Winston. Retrieved on Dec 07th 2020

https:/ / www.neliti.com/id/search?q=theory $\% 20$ of $\% 20$ figurative $\% 2$

0language\&language $=$ en\&sort_by $=$ recent

Let it rain song lyrics. Retrieved March, 10, 2021

https://www.azlyrics.com/lyrics/bonjovi/letitrain.html

Paddmawati, Ni Kadek Sri Rahayu. (2019) entitled "An Analysis of Figurative Language Used in Advertisements in Bali Advertiser Newspaper. Thesis Bali. English Study Program College of Foreign Language University Mahasaraswati Denpasar.

Ratna Yuri and Rusdi Noor Rosa (2013) entitled "An Analysis of types of Figurative Language Used in Internet Advertisements. Here is the link:

http:/ / ejournal.unp.ac.id/index.php/ell/article/download/1807/1 545.

Runaway song lyrics. Retrieved March, 10, 2021

https://www.azlyrics.com/lyrics/bonjovi/runaway.html

Song lyric. Retrieved March, 10, 2021

https://en.wikipedia.org/wiki/Lyrics

Story of love song lyrics. Retrieved March, 10, 2021

https:/ / www.azlyrics.com/lyrics/bonjovi/storyoflove.html

Unbroken song lyrics. Retrieved March, 10, 2021

https:/ / www.azlyrics.com/lyrics/bonjovi/unbroken.html

You give love a bad name song lyrics Retrieved March, 10, 2021

https:/ / www.azlyrics.com/lyrics/bonjovi/yougiveloveabadname.h tml 